\title{
Symposium review: The influences of heat stress on bovine mammary gland function ${ }^{1}$
}

\author{
S. Tao, ${ }^{* 2}$ R. M. Orellana, ${ }^{*}$ X. Weng, ${ }^{*}$ T. N. Marins, ${ }^{*}$ G. E. Dahl, $\dagger$ and J. K. Bernard ${ }^{*}$ \\ *Department of Animal and Dairy Science, University of Georgia, Tifton 31793 \\ †Department of Animal Sciences, University of Florida, Gainesville 32611
}

\begin{abstract}
Heat stress reduces cow milk yield and results in a significant economic loss for the dairy industry. During lactation, heat stress lowers milk production by 25 to $40 \%$ with half of the decrease in milk synthesis resulting from the reduced feed intake. In vitro studies indicate that primary bovine mammary epithelial cells display greater rates of programmed cell death when exposed to high ambient temperatures, which may lead to a decrease in the total number of mammary epithelial cells in the mammary gland, partially explaining the lower milk production of lactating cows under heat stress. The function of mammary cells is also altered by heat stress. In response to heat stress, mammary cells display higher gene expression of heat shock proteins, indicating a need for cytoprotection from protein aggregation and degradation. Further, heat stress results in increased gene expression without altering protein expression of mammary epithelial cell junction proteins, and does not substantially influence the integrity of mammary epithelium. These data suggest that the mammary gland strives to maintain cell-to-cell junction integrity by synthesizing more proteins to compensate for protein losses induced by heat stress. During the dry period, heat stress negatively affects mammary gland development by reducing mammary cell proliferation before parturition, resulting in a dramatic decrease in milk production in the subsequent lactation. In addition to mammary growth, the mammary gland of the heat-stressed dry cow has reduced protein expression of autophagic proteins in the early dry period, suggesting heat stress influences mammary involution. Emerging evidence also indicates that heifers born to cows that experience late-gestation heat stress have lower milk yield during their first lactation, implying that
\end{abstract}

\footnotetext{
Received August 22, 2017.

Accepted November 25, 2017.

${ }^{1}$ Presented as part of the ADSA Lactation Symposium: The New and Old of Mammary Gland Physiology and Milk Synthesis at the ADSA Annual Meeting, Pittsburgh, Pennsylvania, June 2017.

${ }^{2}$ Corresponding author: stao@uga.edu
}

the maternal environment may alter mammary gland development of the offspring. It is not clear if this is due to a direct epigenetic modification of prenatal mammary gland development by maternal heat stress. More research is needed to elucidate the effect of heat stress on mammary gland development and function.

Key words: heat stress, mammary gland, lactation

\section{INTRODUCTION}

Thermal stress is defined as "any change in the thermal relation between an organism and its environment which, if uncompensated by temperature regulation, would result in hyper-, or hypothermia" (IUPS Thermal Commission, 2001). Therefore, in this review, heat stress is defined as an environment that skews the balance between heat load and heat dissipation inducing hyperthermia of an animal. Animals display the maximal genetic potential only within their thermoneutral zone, and a heat challenge above an animal's upper critical temperature dramatically alters behavior, health, and productivity. In the livestock industry, heat stress is a primary constraint to efficient production of animal protein and food security (Baumgard and Rhoads, 2013), resulting in economic burdens to producers and raising serious animal welfare concerns (St-Pierre et al., 2003; Rhoads et al., 2013). In the dairy industry, the decrease in milk production in lactating cows caused by heat stress alone results in a $\$ 1.2$ billion annual loss across the entire US dairy sector (Key et al., 2014). Recent research further indicates that lack of cooling during the dry period could result in a $\$ 850$ million annual loss to the US dairy industry (Ferreira et al., 2016). Production and economic losses caused by heat stress for the dairy industry are increasing due to global climate change (Key et al., 2014). Therefore, there is a need to further understand the mechanisms through which heat stress exerts negative effects on dairy cattle, to develop appropriate management and nutritional countermeasures.

Heat stress compromises reproduction, productivity, and health of a dairy cow (Kadzere et al., 2002; 
West, 2003; Hansen, 2013). Among these negative effects, the decreased milk production and increased bulk milk SCC during summer are the most recognized and directly related to mammary gland function. For example, in Georgia dairy farms (Figure 1), milk yield per cow decreased and the test day SCC increased during summer as average ambient temperature-humidity index (THI) increased. Although the seasonal pattern of milk production and bulk milk SCC on the farm level is a result of various factors, including reproductive, management, and nutritional programs of a farm, a similar pattern is observed in many regions and is largely attributed to the effects of heat stress on dry and lactating dairy cows (West, 2003; Tao and Dahl, 2013). Thus, this symposium paper will focus primarily on the effect of heat stress on lactation performance and aspects related to mammary gland function of a dairy cow at different stages of the lactation cycle.

\section{EFFECTS OF HEAT STRESS DURING THE DRY PERIOD ON MAMMARY GLAND DEVELOPMENT AND LACTATION}

The dry period is a nonlactating period between lactations that functions to promote removal of senescent cells within the mammary gland and replenishment of new mammary cells by proliferation before parturition (Capuco et al., 1997, 2001); it is thereby important for maximal milk production in the following lactation. Exposure to environmental cues during this period alters mammary gland development and influences subsequent milk production. For example, cows that experience heat stress during late gestation have a significant reduction in subsequent milk production (Collier et al., 1982; do Amaral et al., 2011; Tao et al., 2011, 2012b). Compared with cows supplemented with evaporative cooling during the entire dry period in summer, those without evaporative cooling have $\sim 4$ to $5 \mathrm{~kg} / \mathrm{d}$ lower milk production during the entire next lactation (Tao and Dahl, 2013), suggesting that heat stress during the dry period alters mammary function before calving. Indeed, relative to cooled cows during the dry period, noncooled cows had lower mammary epithelial cell proliferation at $20 \mathrm{~d}$ before expected calving (Tao et al., 2011) but similar mammary gene expression of proteins related to synthesis of milk components in the following lactation (Tao et al., 2013). These data suggest that heat stress during the entire dry period compromises mammary growth during the late dry period without affecting synthetic capacity of mammary epithelial cells during following lactation, leading to lower milk production.

The underlying mechanisms for the reduced mammary growth resulting from heat stress during the dry

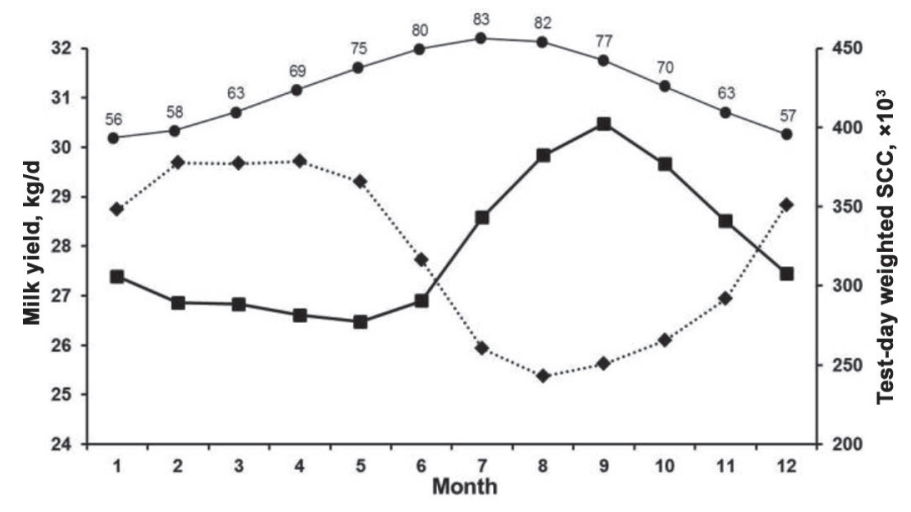

Figure 1. Monthly milk yield [solid diamonds ( ) with a dotted line] and bulk milk SCC [solid square ( $)$ with a solid line] in Georgia (data were extracted from DHIA record of herds in Georgia in 2015, $\mathrm{n}=99$ ) and typical ambient temperature-humidity index [solid circle ( ) with a solid line] within a year in Georgia.

period are not completely understood. Altered postabsorptive metabolism by heat stress may alter nutrient availability at the mammary gland and influence mammary function and growth. In mid-lactation dairy cows, heat stress enhances glucose uptake by tissues rather than the mammary gland (Wheelock et al., 2010), thereby limiting glucose availability and lactose synthesis in the mammary gland. Similar to lactating cows, heat stress reduces dry cows' DMI but to a lesser extent, likely because overall DMI is lower in dry cows. Relative to cooled cows, noncooled cows had 1 to 1.5 $\mathrm{kg} / \mathrm{d}$ reduction in DMI before calving (Tao and Dahl. 2013). However, no differences in plasma glucose, nonesterified fatty acids (NEFA), BHB, and insulin are observed between cooled and noncooled cows during the dry period (do Amaral et al., 2011; Tao et al., 2012b). Consistently, heat stress had no effect on adipose tissue mobilization (Lamp et al., 2015), NEFA response to an insulin challenge, or glucose clearance after a glucose tolerance test (Tao et al., 2012b) during the dry period, suggesting that the postabsorptive fatty acid and glucose metabolism of the cow are not influenced by heat stress during the dry period at the systemic level. In contrast, relative to those under thermal neutrality with similar DMI, heat-stressed dry cows have more pronounced protein mobilization (Lamp et al., 2015). Whether the enhanced extra-mammary protein degradation affects nutrient availability at the mammary gland and thus its development is not clear. Within the mammary gland, noncooled dry cows had higher gene expression of acetyl CoA carboxylase and fatty acid synthetase relative to cooled cows (Adin et al., 2009). Those data may indicate that the mammary gland of heat-stressed dry cows partitions more energy toward fatty acid synthesis rather than mammary cell prolif- 
eration, perhaps reflecting a reduced mammary growth (Adin et al., 2009).

In addition to metabolic responses, heat stress affects hormone synthesis and secretion, which may in turn alter mammary development during the dry period. Heat stress during the dry period increases concentration of plasma prolactin (do Amaral et al., 2009, 2010, 2011; Tao et al., 2011), a lactogenic hormone in dairy cattle (Tucker, 2000), suggesting an altered lactogenesis by heat stress. Collier et al. (1982) first reported a linear relationship between calf birth weight and the subsequent milk yield of dams exposed to heat stress during the last trimester of pregnancy, and suggested that the compromised placental development induced by heat stress during late gestation may be one mechanism to lower mammary growth before calving. Indeed, heat stress during late gestation reduces placental secretion of estrone sulfate, an estrogenic compound that enhances mammary growth (Collier et al., 1982). The blood concentration of placental lactogen also increases as pregnancy advances and has clear positive association with fetal growth rate (Hossner et al., 1997). Heat stress during mid to late pregnancy decreases circulating placental lactogen in sheep (Bell et al., 1989), and although a similar decrease would be expected in cattle, direct confirmation is lacking. Because placental lactogen has lactogenic activity and shares the lactogenic binding sites with prolactin (reviewed by Byatt et al., 1992), the increased prolactin secretion by heat stress during late gestation may reduce the receptor binding of placental lactogen and its lactogenic activity. However, bovine placental lactogen failed to show a lactogenic effect in mammary explant obtained from heifers during mid gestation (Byatt and Bremel, 1986). Evidence for profound effects of placental lactogen on mammary development and function is modest, with placental lactogen causing limited mammogenic responses and milk yield increases during the induced lactation in prepubertal heifers (Byatt et al., 1994, 1997). However, placental lactogen concentrations do not differ between beef and dairy cows, despite their substantial differences in milk yield (Wallace, 1993). Thus, the effect of altered placental secretion of placental lactogen by heat stress during late gestation on mammary growth and function is uncertain, but warrants further investigation.

Interestingly, heat stress may also affect mammary involution. Following milk stasis, mammary involution occurs in the early dry period to clear senescent mammary cells from the previous lactation (Capuco et al., 1997). It is characterized by 2 cellular processes, autophagy (Zarzyńska et al., 2007) and apoptosis (Wilde et al., 1997; Sorensen et al., 2006), which may be influenced by heat stress via altered hormone secretion.
Indeed, prolactin has been shown to decrease apoptosis (Accorsi et al., 2002) and estrogen was reported to induce autophagy in bovine mammary cells (Sobolewska et al., 2009). Thus, heat stress may attenuate mammary involution through the reduced estrone sulfate secretion and increased blood prolactin concentration in the early dry period.

To test this hypothesis, mammary biopsies were collected from both cooled and noncooled cows at $-3,3$, 7,14 , and 22 d relative to dry-off, and the protein expression of markers of autophagic activity [microtubuleassociated protein light chain 3 (LC3)-I, and -II], were assessed by immunoblot (Wohlgemuth et al., 2016). In the mammary gland of cooled cows, protein expression of LC3-I and -II displayed dynamic patterns such that their expression increased after milk stasis and peaked at $7 \mathrm{~d}$ after dry-off. However, mammary expression of both proteins in the mammary gland of noncooled cows maintained constant from late lactation to early dry period, and were lower than cooled cows at $7 \mathrm{~d}$ after dry-off (Wohlgemuth et al., 2016). These observations suggest that heat stress attenuates the mammary involution by blunting the autophagic activity of the mammary gland in the early dry period (Wohlgemuth et al., 2016). However, further study to examine apoptotic profiles of heat-stressed mammary gland during involution is still warranted. Whether the perturbation of mammary involution by heat stress in the early dry period influences subsequent mammary growth in the late dry period is unclear. A recent study (Fabris et al., 2017) reported that the subsequent milk yield of cows that were deprived of cooling during the first half or the second half of the dry period (cooled during the other half) was similar to cows deprived of cooling for the entire dry period, but lower compared with cows that received cooling during the entire dry period. These data suggest that heat stress during either mammary involution in the early dry period, or mammary growth during the late dry period, have similar detrimental effects on future milk production. However, the cellular mechanisms are not completely understood.

In addition to the effect on dams, heat stress during late gestation has strong influences on offspring performance. During the preweaning period, compared with those from cooled dry cows, calves born to noncooled dams had reduced passive and cell-mediated immunity (Tao et al., 2012a; Monteiro et al., 2014), and developed a preference in whole body glucose usage through noninsulin-dependent pathways (Monteiro et al., 2016a). As a result, heifers from noncooled dry cows had a higher chance of leaving the herd due to sickness, growth retardation, or malformation relative to those from cooled dams (Monteiro et al., 2016b). Interestingly, for those that remain in the herd, heifers 
born to noncooled cows had lower milk yield during the first lactation than those from cooled dams (Monteiro et al., 2016b), indicating a carryover effect of maternal heat stress during late gestation on the offspring's mammary development and lactation performance. Events that occurred in the animals' early life, including growth, disease, nutrition, and so on, all influence heifers' productivity in their first lactation (Heinrichs and Heinrichs, 2011). As indicated previously, late gestation heat stress impairs pre-weaned calves' immunity and alters their metabolism, which may in turn affect heifer mammary gland development and future milk production. The milk synthetic capacity of mammary epithelial cells can also be regulated by epigenetic mechanisms, such as DNA methylation (Singh et al., 2012). Skibiel et al. (2017) reported that the mammary gland of heifers born to noncooled dry cows had differentially methylated cytosines located on genes related to cell cycle regulation, epithelial junction, apoptosis, and cell proliferation compared with the mammary gland of heifers from cooled dams, providing evidence that maternal heat stress could alter epigenetic profiles of the developing heifer's mammary gland when she attains lactation. However, whether this phenomenon is due to a direct effect by maternal heat stress in utero or indirect effects by events that occur postnatally is unclear and warrants further investigation. Nevertheless, the impaired lactation performance of heifers by late gestation heat stress is likely due to multiple factors rather than a single mechanism.

\section{EFFECTS OF HEAT STRESS DURING LACTATION ON MILK PRODUCTION AND MAMMARY GLAND FUNCTION}

\section{Effect of Heat Stress in Lactation on Milk Production}

As reviewed by West (2003) and Bernabucci et al. (2010), heat stress during lactation negatively affects milk production. The magnitude of reduction in milk yield by heat stress is influenced by stage of lactation. During summer, the milk yield in a current day of a lactating cow was negatively correlated with the thermal environment $3 \mathrm{~d}$ previous, and early-lactation cows were the least affected compared with mid-lactation cows with late-lactation animals intermediate (Maust et al., 1972). Similarly, Perera et al. (1986) suggested that milk yield of mid-lactation cows was most adversely affected by summer conditions relative to those of early- and late-lactation animals. Control studies to explore the production responses to heat stress at different stages of lactation are limited.

Two studies (S. Tao and G. E. Dahl, unpublished; $\mathrm{X}$. Weng and S. Tao, unpublished) were conducted by our groups and examined milk yield responses of early-, mid-, and late-lactation cows to heat stress. In both experiments, cows were housed in freestall barns but the stall areas of cooled cows were equipped with evaporative cooling, whereas those for noncooled cows were not. Relative to cooled cows, the milk yield of noncooled cows in early lactation (15-45 DIM at the onset of treatment) was similar after 1 wk of treatment but reduced thereafter. Interestingly, the difference of milk yield between cooled and noncooled cows decreased as the average ambient THI decreased, and no treatment effect was observed when average THI decreased below 68 or after treatments ceased when all cows were cooled (Figure 2a). These data confirm that the milk yield of lactating dairy cows is negatively affected by heat stress when average THI exceeds 68 (Zimbelman et al., 2009), and suggest that there is no carryover effect of heat stress on milk yield of early-lactation cows. The milk production of a cow is determined by both the number and secretory activity of mammary epithelial cells (Capuco et al., 2003). Therefore, the data suggest that heat stress may not cause a permanent damage to mammary gland development in early lactation. In other words, the decreased DMI and metabolic changes caused by hyperthermia on the systemic level may be the primary driving force for the reduced milk production by heat stress in early lactation. In contrast, deprivation of cooling immediately reduced milk yield in mid (100-180 DIM at the onset of treatment) and late (180-300 DIM at the onset of treatment) lactation (Figure $2 \mathrm{~b}$ and $2 \mathrm{c}$, respectively). Similar to early-lactation cows, previously cooled and noncooled late-lactation cows had similar milk yield after the cessation of treatments. However, previously noncooled mid-lactation cows maintain a lower milk yield compared with previously cooled cows even after the cessation of treatments when all cows were cooled, suggesting that heat stress may permanently alter mammary gland development after peak lactation. Thus, the reduced milk yield with heat stress may result from different mechanisms at different stages of lactation and the mammary gland of early-, mid-, and late-lactation cows may respond differently to heat stress.

\section{Effect of Heat Stress in Lactation on DMI, Mammary Blood Flow, and Nutrient Uptake}

Milk synthesis and mammary development of dairy cattle are coordinated events that are influenced not only by hyperthermia-related cellular insults in the mammary gland but also by altered DMI, systemic metabolism, and associated mammary nutrient uptake. The decrease in DMI caused by heat stress is an important factor resulting in reduced milk production. In 

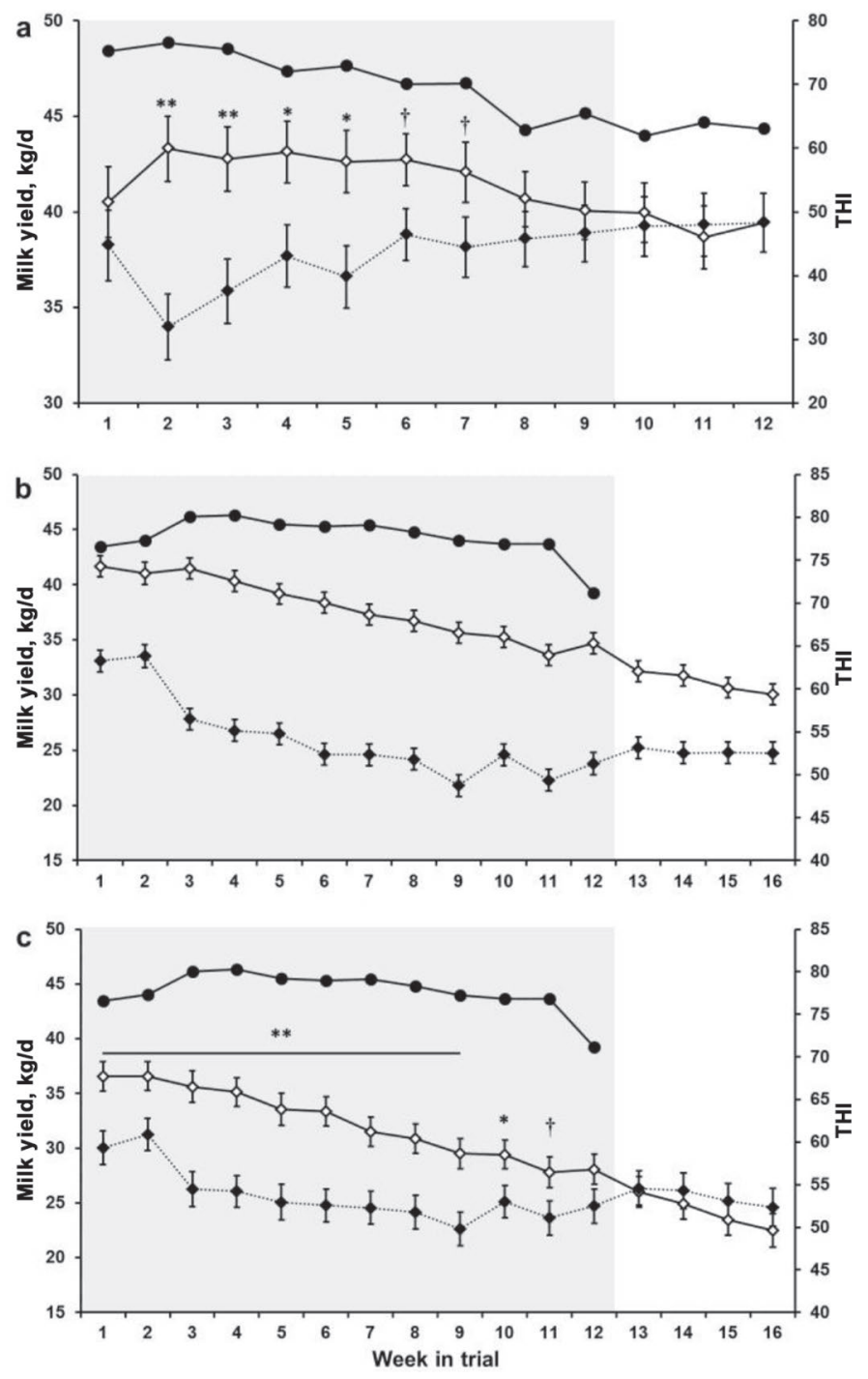

Figure 2. Milk production of cows provided with [CL, open diamonds $(\diamond)$ with a solid line] or without [NC, solid diamonds $(\diamond)$ with a dotted line] active cooling in early (a), mid (b), and late (c) lactation. The solid circle $(\bullet)$ with a solid line represents temperature-humidity index (THI), and the shaded areas represent treatment periods when cows were either cooled or not. After the cessation of treatments, all cows were cooled. At the onset of experiment, the DIM of early-, mid-, and late-lactating cows were 15 to 45,100 to 180 , and 180 to 300 , respectively. The THI data after cessation of treatments in mid and late lactation are not available. In early lactation $(\mathrm{n}=9$ per treatment), effect of treatment $(P=0.13)$, time $(P<0.01)$, treatment by time interaction $(P<0.01)$. In mid lactation $(\mathrm{n}=17$ for $\mathrm{CL}, \mathrm{n}=15$ for NC), effect of treatment $(P<0.01)$, time $(P<0.01)$, treatment by time interaction $(P<0.01)$; however, the SLICE function of SAS suggested that the $P$-values for treatment effect at individual weeks were all below 0.01 . In late lactation ( $\mathrm{n}=19$ for $\mathrm{CL}, \mathrm{n}=17$ for $\mathrm{NC})$, effect of treatment $(P=0.03)$, time $(P<0.01)$, treatment by time interaction $(P<0.01)$. ${ }^{* *} P \leq 0.01,{ }^{*} P \leq 0.05, \dagger P \leq 0.10$.

mid-lactation cows, early study (McGuire et al., 1989) suggested that the reduction in milk yield by heat stress is solely due to the decrease in DMI. However, a recent study (Wheelock et al., 2010) reported that the decreased DMI in heat-stressed mid-lactation cows $(\sim 120$ DIM) only accounts for $\sim 50 \%$ of the reduction in milk yield, suggesting that factors other than DMI during heat stress influence milk synthesis in mid lactation. Similarly, in mid ( $\sim 80$ DIM) and late $(\sim 195$ DIM) lactation, noncooled cows produced less milk but maintained similar DMI relative to cooled cows (Chan et al., 1997; Tarazón-Herrera et al., 1999). In contrast, in early lactation, compared with pair-fed cows under thermal neutrality, heat-stressed cows had similar reductions in milk yield (Lamp et al., 2015), indicating that the decreased DMI of heat-stressed cows in early lactation may account for all the reduction in milk yield. Further, our data (Figure 3; S. Tao and G. E. Dahl, unpublished) suggest that both cooled and noncooled cows had similar feed efficiency (FCM/DMI) in early lactation, indirectly supporting that the decrease in DMI with heat stress in early lactation is the major mechanism reducing milk yield.

Heat stress is accompanied by dramatic changes in blood concentrations of metabolites and systemic metabolic responses. Relative to cooled cows, noncooled cows have reduced plasma concentrations of glucose, BHB, NEFA, and triglycerides (Marins et al., 2017), presumably due to decreased DMI and lower requirements for milk synthesis associated with reduced milk yield. Further, cows exposed to heat stress display inhibited peripheral adipose tissue lipolysis (Wheelock et al., 2010; Lamp et al., 2015) and emphasize glucose utilization in extra-mammary tissues (Wheelock et al., 2010), suggesting distinct metabolic responses to heat stress. Because of the altered systemic metabolism, it is anticipated that heat stress influences the nutrient availability and uptake of the mammary gland. Mammary uptake of nutrients is determined

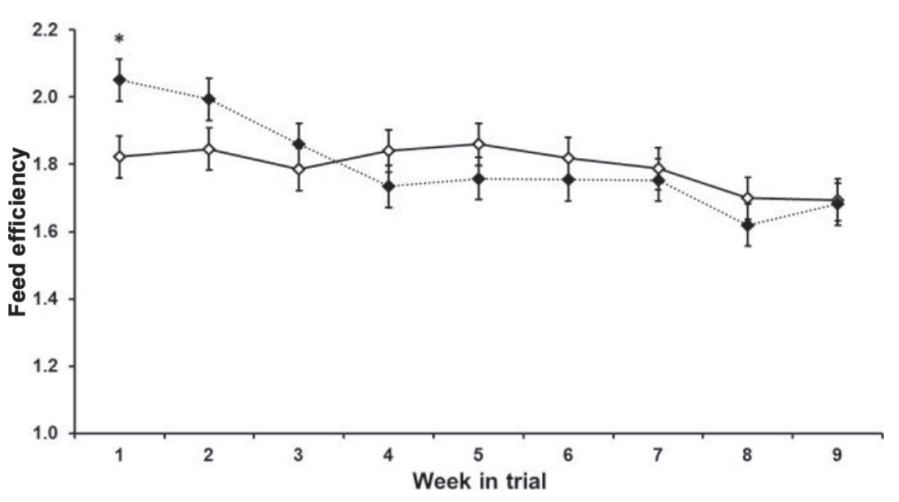

Figure 3. Feed efficiency (FCM/DMI) of cows provided with [open diamonds $(\diamond)$ with solid line] or without [solid diamonds $(\diamond)$ with dotted line] active cooling in early lactation $(\mathrm{n}=9$ per treatment, DIM $\approx 15-45$ at the onset of experiment). Effect of treatment $(P=$ $0.94)$, time $(P<0.01)$, and treatment by time interaction $(P<0.01)$. $* P \leq 0.05$. 
by arteriovenous concentration difference of nutrients and mammary blood flow (Pacheco-Rios et al., 2001; Chaiyabutr, 2012), and elucidation of effects of heat stress on both factors is critical to understand mammary nutrient uptake. Blood flow to bovine mammary gland plays a key role in providing adequate nutrients to support milk synthesis (Prosser et al., 1996). In midlactation dairy goats, exposure to heat stress tended to reduce mammary plasma flow relative to thermal neutrality (Sano et al., 1985). Similarly, the mammary blood flow of mid-lactation cows with ad libitum intake tended to be lower when exposed to heat stress relative to thermal neutrality, but was similar compared with thermal neutrality with restricted feeding (Lough et al., 1990), suggesting that mammary blood flow is responsive to DMI rather than thermal environment per se. Indeed, when fed the same amount of DM, mammary blood flow of lactating sows was higher when exposed to $28^{\circ} \mathrm{C}$ compared with $20^{\circ} \mathrm{C}$ (Renaudeau et al., 2003). In rabbits, Lublin and Wolfenson (1996) observed a $35 \%$ decrease in mammary blood flow of nonpregnant rabbits in early lactation when exposed to acute heat stress compared with thermal neutrality, but no differences were observed at peak lactation. Research on mammary nutrient extraction in farm animals during heat stress is scarce. In mid lactation goats, relative to thermal neutrality, short-term exposure to heat stress (4 d) tended to reduce the arteriovenous concentration difference of glucose, which, coupled with the reduced mammary plasma flow, resulted in a net decrease in mammary glucose uptake (Sano et al., 1985). In contrast, the mammary gland of lactating sows exposed to high ambient temperature $\left(28^{\circ} \mathrm{C}\right)$ had greater mammary extraction rates of glucose and triglyceride, and tended to have greater extraction of $\alpha$-amino acid $\mathrm{N}$ compared with those under thermal neutrality $\left(20^{\circ} \mathrm{C}\right)$, leading to an increase in mammary nutrient uptake (Renaudeau et al., 2003). However, data presented by Renaudeau et al. (2003) need to be interpreted with caution when applied to lactating ruminants because of the distinct differences between ruminants and monogastric animals in mammary gland metabolism (Bauman and Davis, 1975). In lactating dairy cows (T. N. Marins and S. Tao, unpublished data), relative to those exposed to active cooling, the mammary biopsies of noncooled cows in mid to late lactation had similar gene expression of lipoprotein lipase and glucose transporter-I at 7 and 56 $\mathrm{d}$ after deprivation of cooling, suggesting that mammary nutrient transporters are not strongly influenced by prolonged exposure to heat stress (i.e., more than 1 wk). Because mammary biopsy is a homogenate of difference cell types, including immune cells, fibroblasts, endothelial cells, mammary epithelial cells, and so on, how heat stress influences the nutrient uptake of mam- mary epithelial cells in vivo is not entirely understood. Nevertheless, current knowledge of the effect of heat stress on mammary nutrient uptake is lacking, and future studies should emphasize the effect of acute and prolonged exposure to heat stress on mammary blood perfusion and nutrient extraction, and their effects on mammary gland metabolism and development at different stages of lactation.

\section{Effect of Heat Stress on Milk Composition}

Due to the lower milk yield, heat stress normally reduces the yields of milk components; however, the effect of heat stress on milk concentrations of fat and protein is not consistent. As reported by Heck et al. (2009) and Bernabucci et al. (2015), milk fat percentage is reduced during summer relative to winter. In contrast, other studies found that summer climate did not affect (Hammami et al., 2015) or increased (Smith et al., 2013) milk fat percentage of cows relative to temperate seasons. In controlled experiments, similar inconsistency was observed. The milk fat percentage of heat-stressed or noncooled cows was decreased (Moody et al., 1971), not changed (Knapp and Grummer, 1991; Flamenbaum et al., 1995; Tarazón-Herrera et al., 1999), or increased (Garner et al., 2016) compared with that of cows exposed to thermal neutrality or provided with cooling.

However, regardless of the effect on total milk fat percentage, heat stress has a relatively consistent trend to alter milk fatty acid composition. When comparing the test day data of cows under heat stress (THI $\geq 62$ ) and temperate (THI <62) conditions, Hammami et al. (2015) reported that milk fat of samples collected during heat stress tended to have higher proportions of long-chain fatty acids (>C16) but lower proportions of short- (C4-10) and medium-chain (C12-16) fatty acids compared with those collected during temperate conditions. Similarly, milk fat collected from cows during summer contains lower percentages of de novo but higher percentages of preformed fatty acids relative to those collected during winter (Heck et al., 2009). Consistent results were also observed in studies under controlled environments. Relative to those under thermal neutrality, cows exposed to heat stress produced milk containing lower proportions of short- to medium-chain $(<\mathrm{C} 16)$ fatty acids (Richardson et al., 1961; Moody et al., 1971; Liu et al., 2017) and higher (>C16) proportions of long-chain fatty acids (Liu et al., 2017). The degree of milk fatty acid saturation may also be affected by environment. Relative to those collected in temperate climates, milk samples collected during heat stress contain a higher percentage of UFA and a correspondingly lower proportion of SFA (Heck et 
al., 2009; Hammami et al., 2015). However, inconsistent results were reported in studies in controlled environments. Early studies (Richardson, 1961; Moody et al., 1971) suggested that exposure to heat stress decreased the percentage of $\mathrm{C} 18: 1$ of milk fat, the predominant UFA in milk, relative to thermal neutrality. In contrast, a recent study reported that the proportion of C18:1 of milk fat was increased by heat stress (Liu et al., 2017). Biologically, the melting point of body lipid is positively related to the body temperature, such that higher body temperature is associated with higher lipid melting point (review by Neidleman, 1987). Relative to long-chain fatty acids, short-chain fatty acids have lower melting points. Thus, the altered chain length of milk fatty acid by heat stress may represent a biological adaptation to increase lipid melting point in response to higher body temperature. Following this concept, the degree of saturation of fatty acid should decrease under heat stress to further increase the melting point of lipid. However, many factors, such as rumen fermentation and pH (Mishra et al., 1970; Schneider et al., 1988), are also affected by heat stress, which may in turn change milk fatty acid synthesis and composition. Future studies are needed to further understand the exact mechanisms of altered rumen fermentation associated with heat stress on milk fatty acid composition.

The effect of heat stress on milk protein percentage is also inconclusive. In observational studies, milk protein percentage is either reduced during summer relative to temperate conditions (Heck et al., 2009; Smith et al., 2013; Bernabucci et al., 2015) or not affected by seasons (Hammami et al., 2015). Similar inconsistency is also found in studies in controlled environments. Compared with cows under thermal neutrality or active cooling, heat-stressed or noncooled cows had decreased (Knapp and Grummer, 1991; Cowley et al., 2015; Gao et al., 2017), similar (Taylor et al., 1991; Weng et al., 2018), or increased (Tarazón-Herrera et al., 1999) milk protein percentage. Discrepancies among studies may suggest that factors other than heat stress, such as different dietary composition, stage of lactation, degree of heat stress, experimental models used, cooling facilities, length of treatments, and so on, influence the milk composition of a cow in response to heat stress.

\section{Mammary Cellular Responses to Heat Stress}

Although outside the abdomen wall, the mammary gland's internal temperature is highly correlated with a cow's core body temperature (Bitman et al., 1984) and increases when exposed to heat stress (Brown et al., 1977). The increased milk temperature of a heatstressed cow also indirectly supports an elevation of internal mammary temperature (West et al., 2003).
Thus, cells within the mammary gland are exposed to higher temperatures when a cow is under heat stress, and display corresponding heat shock responses. Upon exposure to elevated ambient temperature in vitro, microarray analyses reported that bovine mammary epithelial cells downregulated the expression of genes involved in cell structure, biosynthesis, and transport, and upregulated the gene expression in protein repair and degradation, suggesting coordinated cellular responses to ensure cell survival (Collier et al., 2006; Li et al., 2015).

Interestingly, as reviewed by Richter et al. (2010), cells do not recognize temperature per se, and the heat shock responses of a cell are elicited by accumulated unfolded proteins induced by other stressors, such as oxidative stress, related to heat stress. Indeed, the production of heat shock proteins (HSP) is the most recognized cellular responses by heat stress to facilitate protein folding as molecular chaperones. Under in vitro conditions, when bovine mammary epithelial cells were incubated under a constant temperature of $42^{\circ} \mathrm{C}$ for $24 \mathrm{~h}$, the gene expression of HSP 70 sharply increased but returned to basal level after $8 \mathrm{~h}$ of incubation at $42^{\circ} \mathrm{C}$, suggesting that prolonged exposure to heat shock results in a loss of thermal tolerance of mammary epithelial cells in vitro (Collier et al., 2006). In contrast, Orellana et al. (2017b) observed that gene expression of HSP 27, 70, and 90 in mammary biopsies collected from noncooled cows was elevated compared with cooled cows at 7 and $56 \mathrm{~d}$ after deprivation of cooling, indicating that mammary cells display heat shock responses during both acute and chronic heat stress in vivo.

Beyond protein denaturation and unfolding, heat stress results in abnormal cell morphology. In primary mouse mammary epithelial cells cultured in vitro (Shyy et al., 1989), brief exposure (15-30 min) to extreme temperatures $\left(43-45^{\circ} \mathrm{C}\right)$ resulted in degradation of actin filaments and retraction of keratin filaments from the plasma membrane to form perinuclear aggregates without changing protein expression, suggesting a reorganization of the cytoskeleton due to heat shock. As a result, cellular organelles, such as mitochondria and lysosomes, are re-localized to the perinuclear area upon exposure to heat shock (Shyy et al., 1989). Interestingly, the reorganization of the cytoskeleton was not observed when mouse mammary epithelial cells were exposed to a lower temperature $\left(41^{\circ} \mathrm{C}\right.$, Shyy et al., 1989), indicating different cellular responses of mammary epithelial cells under different degree of heat shock. In the bovine, relative to those incubated at $37^{\circ} \mathrm{C}$, exposure to $42^{\circ} \mathrm{C}$ immediately reduced the ductal structure of mammary epithelial cells and completely ablated cell ductal extension after $24 \mathrm{~h}$ incubation (Collier et al., 2006). However, to the best of our knowledge, examination of 
heat stress on intracellular structure of bovine mammary epithelial cells in vivo is still not available.

The cellular heat shock responses are adaptive mechanisms to cope with hyperthermia and are essential to the survival of a cell under heat stress (Richter et al., 2010). However, if the defects exceed the countermeasures, heat stress will lead to cell death. In vitro, exposure to high ambient temperature causes the arrest of cell proliferation and induces apoptosis of bovine mammary epithelial cells (Collier et al., 2006; Du et al., 2008; Li et al., 2015). The trigger of apoptosis by heat shock is not completely understood. Du et al. (2008) reported that a heat shock treatment applied to bovine mammary epithelial cells in vitro lead to swollen mitochondria and decreased mitochondrial transmembrane potential, which could result in the release of proapoptotic factors, such as cytochrome $\mathrm{C}$, and induce apoptosis. In contrast, as reviewed by Riezman (2004), the intracellular accumulation of aggregated, unfolded, and denatured proteins caused by heat stress is toxic to mammalian cells, and may be another mechanism of heat stress induced apoptosis. The influence of heat stress on bovine mammary development during lactation under in vivo conditions is largely unknown. In a recent study (Orellana et al., 2017a), mammary biopsies were collected at 7 and $56 \mathrm{~d}$ of the treatment (deprivation of cooling for noncooled cows) from cooled and noncooled cows during mid to late lactation to examine mammary apoptosis and cell proliferation by terminal deoxynucleotidyl transferase dUTP nick end labeling and Ki-67 labeling, respectively. Relative to cooled cows, terminal deoxynucleotidyl transferase dUTP nick end labeling of the mammary gland of noncooled cows was numerically higher at $7 \mathrm{~d}$ but not statistically different at either sampling date, suggesting that prolonged exposure to heat stress (over a week) has no effect on mammary apoptosis of a lactating dairy cow. However, the possibility that extensive mammary apoptosis occurs within 1 wk of heat exposure cannot be excluded. Surprisingly, the mammary gland of noncooled cows had a higher Ki-67 labeling at $56 \mathrm{~d}$ of the treatment compared with cooled cows, indicating greater proliferation of mammary cells of lactating cows exposed to chronic heat stress. The cellular mechanism driving increased mammary growth by prolonged heat exposure is unknown, but may reflect an adaptive response to compensate for reduced milk synthesis. Clearly, more work is needed to elucidate the effect of heat stress on bovine mammary gland development in vivo. Further, because most of the cell culture studies used extreme incubation temperatures that are much greater than body temperature of a heat-stressed cow, the results obtained from these studies may not entirely represent the cellular events occurring in vivo. Thus, cell culture studies using an incubation temperature within the physiological range of a heat-stressed cow are still warranted.

\section{Effect of Heat Stress in Lactation on Mammary Epithelial Cell Junction and Health}

In the mammary gland, the adjacent mammary epithelial cells form a 3-dimensional structure, also called a junctional complex (Stelwagen and Singh, 2014). The junctional complex is composed of a tight junction beneath the apical surface of epithelium, the adjacent adherens junction, and a desmosome (reviewed by Itoh and Bissell, 2003; Tsukita et al., 2008; Turner, 2009), architecture that serves to maintain impermeability of mammary epithelium and to regulate paracellular transport of ions and small molecules across the blood-milk barrier of mammary gland during lactation (Nguyen and Neville, 1998; Stelwagen and Singh, 2014). Challenges of the mammary gland, such as lower milking frequency and mastitis, decrease milk yield of lactating dairy cows, and are accompanied by disrupted mammary epithelial integrity (Stelwagen et al., 1994a,b). Thus, the intact mammary epithelial barrier is a prerequisite to maintain maximal milk production and is a proper indicator of optimal mammary function.

Heat stress negatively influences the integrity of the epithelial junction. Previous studies conducted under in vitro conditions reported that heat shock increased the permeability of epithelial junctions formed by canine (Moseley et al., 1994) and porcine kidney epithelial cells (Ikari et al., 2005) and human colon and kidney epithelial cells (Dokladny et al., 2016). Similarly, under in vivo conditions, heat stress impaired the integrity of intestinal epithelium in swine (Pearce et al., 2013, 2014; Sanz Fernandez et al., 2014), rodents (Lambert et al., 2002), and monkeys (Dokladny et al., 2016). However, studies examining the effects of heat stress on mammary epithelial tissue permeability in lactating animals are limited. A recent study was conducted to explore the mammary epithelial integrity between cooled and noncooled cows in mid to late lactation (Weng et al., 2018). Relative to cooled cows, deprivation of cooling had no overall effect on concentrations of plasma lactose and milk BSA during a 12-wk experimental period but tended to increase the plasma lactose concentration immediately after initiation of treatments (Weng et al., 2018). Those data suggest that heat-stressed mammary gland in lactating cows is capable of maintaining the overall integrity of mammary epithelium, but acute heat stress temporarily causes the leakage of lactose from mammary gland. In mammary tissue, deprivation of cooling upregulated gene expression of epithelial cell junction-related proteins (occludin, claudin-1, zonula occludens- 1 and -2 , and E-cadherin), but did not af- 
fect the protein expression of occludin and E-cadherin (Weng et al., 2018). In mammalian cells, heat stress induces extensive protein denaturation and degradation (Richter et al., 2010; Flick and Kaiser, 2012). Therefore, it is possible that heat stress causes a net loss of epithelial junction related proteins, and the heat-stressed mammary gland strives to regenerate those proteins by increasing their gene expression, to maintain the proper mammary epithelial integrity. However, even increased gene expression may not result in upregulation of protein synthesis. The exact cellular mechanism of these observations is currently unknown, but may represent an adaptive mechanism to shift energy and nutrient to support critical functions in mammary gland, such as epithelial integrity, at the expense of milk synthesis.

As indicated in Figure 1, there is a seasonal effect on milk quality in dairy farms. Similarly, in a study including 300 Dutch dairy farms, Olde Riekerink et al. (2007) reported that the highest bulk milk SCC was observed from August to September, and individual cows had the highest probability to have milk SCC above 200,000 cells/mL in August. In the same study, authors also reported the highest incidence rate of clinical mastitis caused by Streptococcus uberis and Escherichia coli in summer compared with other seasons (Olde Riekerink et al., 2007). In a survey of 9 US dairies, Hogan et al. (1989) reported the highest incidence of clinical mastitis occurred during summer relative to other seasons. In a study including 2 Florida dairy herds, Elvinger et al. (1991b) reported that cows in the summer (July to October) had greater incidence of inflammation events of mammary gland (defined as an increase of $\log _{2}[\mathrm{SCC}]$ of at least 1 unit above the baseline $\log _{2}[\mathrm{SCC}]$ of a cow) compared with those in the fall (October to January). Therefore, the summer condition is not only related to impaired milk quality but also associated with high incidence of mammary infection. This phenomenon may attribute to a combination of indirect environmental effects and direct animal factors (Kadzere et al., 2002; Hogan and Smith, 2012). During summer, elevated ambient temperature and humidity support greater growth and survival of pathogens compared with the cold and dry conditions of winter (Kadzere et al., 2002), which increases the pathogen load. In addition to the increased threat from pathogens, immune function of a cow is impaired in response to heat stress. Peripheral blood mononuclear cells isolated from normothermic dairy cows have a lower mitogen-induced proliferative capacity in vitro when incubated under elevated ambient temperatures (Kamwanja et al., 1994; Lacetera et al., 2006). Similarly, exposure to heat stress during the dry period reduced early-lactation cows' peripheral blood mononuclear cell proliferation and tumor necrosis factor- $\alpha$ production when encounter- ing a mitogen ex vivo, suggesting a compromised cellmediated immune function by heat stress (do Amaral et al., 2010). Further, the random migration of neutrophils from thermo-neutral cows in vitro is reduced but neutrophil phagocytosis and oxidative burst are not influenced under elevated incubation temperatures (Elvinger et al., 1991a). When heat stress is applied to lactating cows, neutrophil chemotaxis is depressed ex vivo (Elvinger et al., 1991a) and heat-stressed lactating cows have decreased leukocyte migration into the mammary gland in response to a chemotactic challenge of oyster glycogen (Elvinger et al., 1992). Therefore, the compromised immune function in vitro and in vivo under heat stress may partly explain the increases in milk SCC and incidence of clinical mastitis in summer in comparison to winter.

However, in contrast to results obtained from observational studies on the farm level, control studies suggested that hyperthermia induced by heat stress alone may not have direct influence on milk SCC. In lactation, compared with thermo-neutral (Wheelock et al., 2010) or cooled (Chan et al., 1997; Tarazón-Herrera et al., 1999; Weng et al., 2018) cows, heat-stressed or noncooled cows had similar milk SCC. The effect of heat stress during the dry period on milk SCC in the subsequent lactation is not consistent. Relative to prepartum cooled cows, noncooled cows during the dry period tend to have higher (Tao et al., 2011; Senn et al., 2017) or have similar milk SCC (Tao et al., 2012b; Thompson et al., 2014b) in the subsequent lactation. Further, heat stress in the dry period has no influence on the incidences of clinical mastitis in the following lactation (Thompson et al., 2014a). To further understand lactating cows' response to mammary inflammation under heat stress, an intramammary (im) LPS challenge was performed on cooled and noncooled cows in lactation (Monteiro et al., 2016c). In response to im-LPS infusion, milk SCC increased substantially and reached the peak at $12 \mathrm{~h}$ following im-LPS challenge regardless of treatments. No difference in milk SCC was observed between cooled and noncooled cows during the first 48 $\mathrm{h}$ after im-LPS challenge, but noncooled cows showed a faster reduction in milk SCC compared with cooled cows thereafter (Monteiro et al., 2016c), suggesting a more rapid clearance of milk SCC of noncooled cows. Interestingly, noncooled cows had greater reductions in blood concentrations of lymphocytes, neutrophils, $\mathrm{Fe}$, and $\mathrm{Zn}$ relative to cooled cows during the first $12 \mathrm{~h}$ after im-LPS challenge (Monteiro et al., 2016c). Mammary inflammation induced by LPS is related to excessive production of oxidative metabolites in milk (Silanikove et al., 2012), suggesting the occurrence of oxidative stress in the mammary gland. Further, imLPS challenge increases mammary gene expression of 
lactoferrin (Vernay et al., 2012) and its milk concentration (Silanikove et al., 2012) as a countermeasure to diminish mammary inflammation (Legrand, 2016). It is known that trace minerals, such as $\mathrm{Zn}$ and $\mathrm{Fe}$, are critical components of antioxidative enzymes and lactoferrin, and function as modulators in immune system (Fukai and Ushio-Fukai, 2011; Bonaventura et al., 2015; Legrand, 2016). Thus, these data may indicate that the mammary gland of noncooled cows requires greater immune cell infiltration and micromineral availability to cope with local inflammation relative to cooled cows. This may be due to either an impaired functionality of systemic immune cells with heat stress as described previously, or a compromised local immune function within the mammary gland under heat stress, or both. Future studies under in vitro and in vivo conditions are warranted to obtain additional insights of the altered immune responses of mammary cells under heat stress.

\section{CONCLUSIONS}

Relative to metabolic studies, research to examine heat stress effects on the mammary gland in ruminants is limited. Available data suggest that heat stress during different stages of a cow's lactation cycle has negative effects on productivity. During the dry period, heat stress results in impaired mammary growth, leading to reduced milk yield in the subsequent lactation. Emerging evidence also suggest that offspring born to heatstressed cows during late gestation had compromised future performance, potentially as a result of epigenetic modification. During lactation, the biological mechanisms of the negative effects of heat stress on milk yield may differ in cows at different stages of lactation, but the altered mammary gland development may partly contribute to reduced milk synthesis. Further, the effects of heat stress on milk composition and quality are inconclusive.

\section{ACKNOWLEDGMENTS}

The authors thank the staff of the Dairy Research Center of the University of Georgia (Tifton, GA) and the Dairy Unit of the University of Florida (Hague, FL) for animal care and data collection. Appreciation is expressed to Zinpro Corporation (Eden Prairie, MN) and Pancosma S. A. (Geneva, Switzerland) for financial support of studies described herein.

\section{REFERENCES}

Accorsi, P. A., B. Pacioni, C. Pezzi, M. Forni, D. J. Flint, and E. Seren. 2002. Role of prolactin, growth hormone and insulin-like growth factor 1 in mammary gland involution in the dairy cow. J. Dairy Sci. 85:507-513.
Adin, G., A. Gelman, R. Solomon, I. Flamenbaum, M. Nikbachat, E. Yosef, A. Zenou, A. Shamay, Y. Feuermann, S. J. Mabjeesh, and J. Miron. 2009. Effects of cooling dry cows under heat load conditions on mammary gland enzymatic activity, intake of food water, and performance during the dry period and after parturition. Livest. Sci. 124:189-195.

Bauman, D. E., and C. L. Davis. 1975. Regulation of lipid metabolism. In Digestion and metabolism in the ruminant. I. W. McDonald and A. C. I. Warner, ed. The Univ. New England Publ. Unit., Armidale, Australia. 1975:496.

Baumgard, L. H., and R. P. Rhoads Jr. 2013. Effects of heat stress on postabsorptive metabolism and energetics. Annu. Rev. Anim. Biosci. 1:7.1-7.27.

Bell, A. W., B. W. McBride, R. Slepetis, R. J. Early, and W. B. Currie. 1989. Chronic heat stress and prenatal development in sheep: I. Conceptus growth and maternal plasma hormones and metabolites. J. Anim. Sci. 67:3289-3299.

Bernabucci, U., L. Basirico, P. Morera, D. Dipasquale, A. Vitali, F. Piccioli Cappelli, and L. Calamari. 2015. Effect of summer season on milk protein fractions in Holstein cows. J. Dairy Sci. 98:18151827.

Bernabucci, U., N. Lacetera, L. H. Baumgard, R. P. Rhoads, B. Ronchi, and A. Nardone. 2010. Metabolic and hormonal acclimation to heat stress in domesticated ruminants. Animal 4:1167-1183.

Bitman, J., A. Lefcourt, D. L. Wood, and B. Stroud. 1984. Circadian and ultradian temperature rhythms of lactating dairy cows. J. Dairy Sci. 67:1014-1023.

Bonaventura, P., G. Benedetti, F. Albarede, and P. Miossec. 2015. Zinc and its role in immunity and inflammation. Autoimmun. Rev. 14:277-285.

Brown, R. W., J. L. Thomas, H. M. Cook, J. L. Riley, and G. D. Booth. 1977. Effect of environmental temperature stress on intramammary infections of dairy cows and monitoring of body and intramammary temperatures by radiotelemetry. Am. J. Vet. Res. $38: 181-187$.

Byatt, J. C., and R. D. Bremel. 1986. Lactogenic effect of bovine placental lactogen on pregnant rabbit but not pregnant heifer mammary gland explants. J. Dairy Sci. 69:2066-2071.

Byatt, J. C., P. J. Eppard, J. J. Weenhuizen, T. L. Curran, D. F. Curran, M. F. McGrath, and R. J. Collier. 1994. Stinulation of mammogenesis and lactogenesis by recombinant bovine placental lactogen in steroid-primed dairy heifers. J. Endocrinol. 140:33-43.

Byatt, J. C., R. H. Sorbet, P. J. Eppard, T. L. Curran, D. F. Curran, and R. J. Collier. 1997. The effect of recombinant bovine placental lactogen on induced lactation in dairy heifers. J. Dairy Sci. 80:496-503.

Byatt, J. C., W. C. Warren, P. J. Eppard, N. R. Staten, G. G. Krivi, and R. J. Collier. 1992. Ruminant placental lactogens: Structure and biology. J. Anim. Sci. 70:2911-2923.

Capuco, A. V., R. M. Akers, and J. J. Smith. 1997. Mammary growth in Holstein cows during the dry period: quantification of nucleic acids and histology. J. Dairy Sci. 80:477-487.

Capuco, A. V., S. E. Ellis, S. A. Hale, E. Long, R. A. Erdman, X. Zhao, and M. J. Paape. 2003. Lactation persistency: Insights from mammary cell proliferation studies. J. Anim. Sci. 81:18-31.

Capuco, A. V., D. L. Wood, R. Baldwin, K. Mcleod, and M. J. Paape. 2001. Mammary cell number, proliferation, and apoptosis during a bovine lactation: Relation to milk production and effect of bST. J. Dairy Sci. 84:2177-2187.

Chaiyabutr, N. 2012. Control of mammary function during lactation in crossbred dairy cattle in the tropics. Pages 127-154 in Milk Production-Advanced Genetic Traits, Cellular Mechanism, Animal Management and Health. N. Chaiyabutr, ed. InTech. https:// doi.org/10.5772/50763.

Chan, S. C., J. T. Huber, K. H. Chen, J. M. Simas, and Z. Wu. 1997. Effects of ruminally inert fat and evaporative cooling on dairy cows in hot environmental temperatures. J. Dairy Sci. 80:1172-1178.

Collier, R. J., S. G. Doelger, H. H. Head, W. W. Thatcher, and C. J. Wilcox. 1982. Effects of heat stress during pregnancy on maternal hormone concentrations, calf birth weight and postpartum milk yield of Holstein cows. J. Anim. Sci. 54:309-319. 
Collier, R. J., C. M. Stiening, B. C. Pollard, M. J. VanBaale, L. H. Baumgard, P. C. Gentry, and P. M. Coussens. 2006. Use of gene expression microarrays for evaluating environmental stress tolerance at the cellular level in cattle. J. Anim. Sci. 84(Suppl.):E1E13.

Cowley, F. C., D. G. Barber, A. V. Houlihan, and D. P. Poppi. 2015. Immediate and residual effects of heat stress and restricted intake on milk protein and casein composition and energy metabolism. J. Dairy Sci. 98:2356-2368.

do Amaral, B. C., E. E. Connor, S. Tao, M. J. Hayen, J. W. Bubolz, and G. E. Dahl. 2009. Heat-stress abatement during the dry period: Does cooling improve transition into lactation? J. Dairy Sci. 92:5988-5999.

do Amaral, B. C., E. E. Connor, S. Tao, M. J. Hayen, J. W. Bubolz, and G. E. Dahl. 2010. Heat stress abatement during the dry period influences prolactin signaling in lymphocytes. Domest. Anim. Endocrinol. 38:38-45.

do Amaral, B. C., E. E. Connor, S. Tao, M. J. Hayen, J. W. Bubolz and G. E. Dahl. 2011. Heat stress abatement during the dry period influences metabolic gene expression and improves immune status in the transition period of dairy cows. J. Dairy Sci. 94:86-96.

Dokladny, K., M. N. Zuhl, and P. L. Moseley. 2016. Intestinal epithelial barrier function and tight junction proteins with heat and exercise. J. Appl. Physiol. 120:692-701. https://doi.org/10.1152/ japplphysiol.00536.2015.

Du, J., H. S. Di, L. Gu, Z. H. Li, and G. L. Wang. 2008. Hyperthermia causes bovine mammary epithelial cell death by a mitochondrialinduced pathway. J. Therm. Biol. 33:37-47.

Elvinger, F., P. J. Hansen, and R. P. Natzke. 1991a. Modulation of function of bovine polymorphonuclear leukocytes and lymphocytes by high temperature in vitro and in vivo. Am. J. Vet. Res. 52:1692-1698

Elvinger, F., R. C. Littell, R. P. Natzke, and P. J. Hansen. 1991b. Analysis of somatic cell count data by a peak evaluation algorithm to determine inflammation events. J. Dairy Sci. 74:3396-3406.

Elvinger, F., R. P. Natzke, and P. J. Hansen. 1992. Interactions of heat stress and bovine somatotropin affecting physiology and immunology of lactating cows. J. Dairy Sci. 75:449-462.

Fabris, T. F., J. Laporta, A. L. Skibiel, B. D. Senn, F. N. Corra, and G. E. Dahl. 2017. Impact of heat stress during the early and late dry period on subsequent performance in dairy cattle. J. Dairy Sci. 100(Suppl. 2):386. (Abstr.)

Ferreira, F. C., R. S. Gennan, G. E. Dahl, and A. De Vries. 2016 Economic feasibility of cooling dry cows across the United States. J. Dairy Sci. 99:9931-9941.

Flamenbaum, I., D. Wolfenson, P. L. Kunz, M. Maman, and A. Berman. 1995. Interactions between body condition at calving and cooling of dairy cows during lactation in summer. J. Dairy Sci. 78:2221-2229.

Flick, K., and P. Kaiser. 2012. Protein degradation and the stress response. Semin. Cell Dev. Biol. 23:515-522.

Fukai, T., and M. Ushio-Fukai. 2011. Superoxide dismutases: Role in redox signaling, vascular function, and diseases. Antioxid. Redox Signal. 15:1583-1606.

Gao, S. T., J. Guo, S. Y. Quan, X. M. Nan, M. V. S. Fernandez, L. H. Baumgard, and D. P. Bu. 2017. The effects of heat stress on protein metabolism in lactating Holstein cows. J. Dairy Sci. 100:5040-5049.

Garner, J. B., M. L. Douglas, S. R. Williams, W. J. Wales, L. C. Marett, T. T. Nguyen, C. M. Reich, and B. J. Hayes. 2016. Genomic selection improves heat tolerance in dairy cattle. Sci. Rep. 6:34114.

Hammami, H., J. Vandenplas, M. L. Vanrobays, B. Rekik, C. Bastin, and N. Gengler. 2015. Genetic analysis of heat stress effects on yield traits, udder health, and fatty acids of Walloon Holstein cows. J. Dairy Sci. 98:4956-4968.

Hansen, P. J. 2013. Antecedents of mammalian fertility: Lessons from the heat-stressed cow regarding the importance of oocyte competence for fertilization and embryonic development. Anim. Front. 3:34-38.
Heck, J. M. L., H. J. F. van Valenberg, J. Dijkstra, and A. C. M. van Hooijdonk. 2009. Seasonal variation in the Dutch bovine raw milk composition. J. Dairy Sci. 92:4745-4755.

Heinrichs, A. J., and B. S. Heinrichs. 2011. A prospective study of calf factors affecting first-lactation and lifetime milk production and age of cows when removed from the herd. J. Dairy Sci. 94:336-341.

Hogan, J., and K. L. Smith. 2012. Managing environmental mastitis. Vet. Clin. North Am. Food Anim. Pract. 28:217-224.

Hogan, J. S., K. L. Smith, K. H. Hoblet, P. S. Schoenberger, D. A. Todhunter, W. D. Hueston, D. E. Pritchard, G. L. Bowman, L. E. Heider, B. L. Brockett, and H. R. Conrad. 1989. Field survey of clinical mastitis in low somatic cell count herds. J. Dairy Sci. $72: 1547-1556$

Hossner, K. L., M. D. Holland, S. E. Williams, C. R. Wallace, G. D. Niswender, and K. G. Odde. 1997. Serum concentrations of insulin-like growth factors and placental lactogen during gestation in cattle. II. Maternal profiles. Domest. Anim. Endocrinol. $14: 316-324$

Ikari, A., M. Nakano, Y. Suketa, H. Harada, and K. Takagi. 2005. Reorganization of ZO-1 by sodium-dependent glucose transporter activation after heat stress in LLC-PK1 cells. J. Cell. Physiol. 203:471-478.

Itoh, M., and M. J. Bissell. 2003. The organization of tight junctions in epithelia: implications for mammary gland biology and breast tumorigenesis. J. Mammary Gland Biol. Neoplasia 8:449-462.

IUPS Thermal Commission. 2001. Glossary of Terms for Thermal Physiology-Third edition. Jap. J. Physiol. 51:245-280.

Kadzere, C. T., M. R. Murphy, N. Silaninove, and E. Maltz. 2002. Heat stress in lactating dairy cows: A review. Livest. Prod. Sci. $77: 59-91$.

Kamwanja, L. A., C. C. Chase Jr., J. A. Gutierrez, V. Guerriero Jr., T. A. Olsen, A. C. Hammond, and P. J. Hansen. 1994. Responses of bovine lymphocytes to heat shock as modified by breed and antioxidant status. J. Anim. Sci. 72:438-444.

Key, N., S. Sneeringer, and D. Marquardt. 2014. Climate change, heat stress, and U.S. dairy production. USDA-Economic Research Report \#175.

Knapp, D. M., and R. R. Grummer. 1991. Response of lactating dairy cows to fat supplementation during heat stress. J. Dairy Sci. 74:2573-2579.

Lacetera, N., U. Bernabucci, D. Scalia, L. Basiricò, P. Morera, and A. Nardone. 2006. Heat stress elicits different responses in peripheral blood mononuclear cells from Brown Swiss and Holstein cows. J. Dairy Sci. 89:4606-4612

Lambert, G. P., C. V. Gisolfi, D. J. Berg, P. L. Moseley, L. W. Oberley, and K. C. Kregel. 2002. Selected contribution: Hyperthermia-induced intestinal permeability and the role of oxidative and nitrosative stress. J. Appl. Physiol. 92:1750-1761.

Lamp, O., M. Derno, W. Otten, M. Mielenz, G. Nurnberg, and B. Kuhla. 2015. Metabolic heat stress adaption in transition cows: differences in macronutrient oxidation between late-gestating and earlylactating German Holstein dairy cows. PLoS One 10:e0125264.

Legrand, D. 2016. Overview of lactoferrin as a natural immune modulator. J. Pediatr. 173:S10-S15.

Li, L., Y. Sun, J. Wu, X. Li, M. Luo, and G. Wang. 2015. The global effect of heat on gene expression in cultured bovine mammary epithelial cells. Cell Stress Chaperones 20:381-389.

Liu, Z., V. Ezernieks, J. Wang, N. W. Arachchillage, J. B. Garner, W. J. Wales, B. G. Cocks, and S. Rochfort. 2017. Heat stress in dairy cattle alters lipid composition of milk. Sci. Rep. 7:961.

Lough, D. S., D. L. Beede, and C. J. Wilcox. 1990. Effects of feed intake and thermal stress on mammary blood flow and other physiological measurements in lactating dairy cows. J. Dairy Sci. $73: 325-332$.

Lublin, A., and D. Wolfenson. 1996. Lactation and pregnancy effects on blood flow to mammary and reproductive systems in heatstressed rabbits. Comp. Biochem. Physiol. A Physiol. 115:277-285.

Marins, T. N., R. M. Orellana, X.-S. Weng, A. P. A. Monteiro, J.R. Guo, J. K. Bernard, J. M. DeFrain, and S. Tao. 2017. Effect 
of heat stress, dietary zinc sources and intramammary lipopolysaccharide challenge on metabolic responses of lactating Holstein cows. J. Dairy Sci. 100(Suppl. 2):156. (Abstr.)

Maust, L. E., R. E. McDowell, and N. W. Hooven. 1972. Effect of summer weather on performance of Holstein cows in three stages of lactation. J. Dairy Sci. 55:1133-1139.

McGuire, M. A., D. K. Beede, M. A. DeLorenzo, C. J. Wilcox, G. B. Huntington, C. K. Reynolds, and R. J. Collier. 1989. Effects of thermal stress and level of feed intake on portal plasma flow and net fluxes of metabolites in lactating Holstein cows. J. Anim. Sci. 67:1050-1060.

Mishra, M., F. A. Martz, R. W. Stanley, H. D. Johnson, J. R. Campbell, and E. Hilderbrand. 1970. Effect of diet and ambient temperature-humidity on ruminal $\mathrm{pH}$, oxidation reduction potential, ammonia and lactic acid in lactating cows. J. Anim. Sci. 30:10231028.

Monteiro, A. P. A., J.-R. Guo, X.-S. Weng, B. M. Ahmed, M. J. Hayen, G. E. Dahl, J. K. Bernard, and S. Tao. 2016a. Effect of maternal heat stress during the dry period on growth and metabolism of calves. J. Dairy Sci. 99:3896-3907. https://doi.org/10.3168/jds .2015-10699.

Monteiro, A. P. A., S. Tao, I. M. Thompson, and G. E. Dahl. 2014. Effect of heat stress during late gestation on immune function and growth performance of calves: isolation of altered colostral and calf factors. J. Dairy Sci. 97:6426-6439.

Monteiro, A. P. A., S. Tao, I. M. Thompson, and G. E. Dahl. 2016b. In utero heat stress decreases calf survival and performance through the first lactation. J. Dairy Sci. 99:8443-8450. https://doi.org/10 3168/jds.2016-11072.

Monteiro, A. P. A., X.-S. Weng, J.-R. Guo, J. K. Bernard, J. M. DeFrain, and S. Tao. 2016c. Effects of cooling and dietary zinc source on the inflammatory responses to a lipopolysaccharide intra-mammary challenge in lactating Holstein cows during summer. J. Dairy Sci. 99(Suppl.1):555. (Abstr.)

Moody, E. G., P. J. Van Soest, R. E. McDowell, and G. L. Ford. 1971. Effect of high temperature and dietary fat on milk fatty acids. J. Dairy Sci. 54:1457-1460.

Moseley, P. L., C. Gapen, E. S. Wallen, M. E. Walter, and M. W. Peterson. 1994. Thermal stress induces epithelial permeability. Am. J. Physiol. 267:C425-C434.

Neidleman, S. L. 1987. Effects of temperature on lipid unsaturation. Biotechnol. Genet. Eng. Rev. 5:245-268.

Nguyen, D. A., and M. C. Neville. 1998. Tight junction regulation in the mammary gland. J. Mammary Gland Biol. Neoplasia 3:233246.

Olde Riekerink, R. G., H. W. Barkema, and H. Stryhn. 2007. The effect of season on somatic cell count and the incidence of clinical mastitis. J. Dairy Sci. 90:1704-1715.

Orellana, R. M., T. N. Marins, X. Weng, A. P. A. Monteiro, J. Guo, J. K. Bernard, J. DeFrain, D. J. Tomlinson, and S. Tao. 2017b. Effects of heat stress, dietary Zn sources and mammary inflammation on plasma heat shock protein concentration and gene expression of mammary gland in lactating dairy cows during summer. J. Dairy Sci. 100(Suppl. 2):84. (Abstr.)

Orellana, R. M., T. N. Marins, X. Weng, A. P. A. Monteiro, J. Guo, J. K. Bernard, J. M. DeFrain, D. J. Tomlinson, and S. Tao. 2017a. Effects of heat stress and dietary Zn source on cell growth and apoptosis of mammary gland in lactating dairy cows. J. Dairy Sci. 100(Suppl. 2):ii. (Abstr.)

Pacheco-Rios, D., D. D. S. Mackenzie, and W. C. McNabb. 2001. Comparison of two variants of the Fick principle for estimation of mammary blood flow in dairy cows fed two levels of dry matter intake. Can. J. Anim. Sci. 81:57-63. https://doi.org/10.4141/A00 -035 .

Pearce, S. C., V. Mani, T. E. Weber, R. P. Rhoads, J. F. Patience, L. H. Baumgard, and N. K. Gabler. 2013. Heat stress and reduced plane of nutrition decreases intestinal integrity and function in pigs. J. Anim. Sci. 91:5183-5193. https://doi.org/10.2527/jas.2013 -6759 .

Pearce, S. C., M. V. Sanz-Fernandez, J. H. Hollis, L. H. Baumgard, and N. K. Gabler. 2014. Short-term exposure to heat stress attenu- ates appetite and intestinal integrity in growing pigs. J. Anim. Sci. 92:5444-5454. https://doi.org/10.2527/jas.2014-8407.

Perera, K. S., F. C. Gwazdauskas, R. E. Pearson, and T. B. Brumback Jr.. 1986. Effect of season and stage of lactation on performance of Holstein. J. Dairy Sci. 69:228-236.

Prosser, C. G., S. R. Davis, V. C. Farr, and P. Lacasse. 1996. Regulation of blood flow in the mammary microvasculature. J. Dairy Sci. 79:1184-1197.

Renaudeau, D., J. Noblet, and J. Y. Dourmad. 2003. Effect of ambient temperature on mammary gland metabolism in lactating sows. J. Anim. Sci. 81:217-231.

Rhoads, R. P., L. H. Baumgard, J. K. Suagee, and S. R. Sanders. 2013. Nutritional interventions to alleviate the negative consequences of heat stress. Adv. Nutr. 4:267-276.

Richardson, C. W., H. D. Johnson, C. W. Gehrke, and D. F. Goerlitz. 1961. Effects of environmental temperature and humidity on the fatty acid composition of milk fat. J. Dairy Sci. 44:1937-1940.

Richter, K., M. Haslbeck, and J. Buchner. 2010. The heat shock response: Life on the verge of death. Mol. Cell 40:253-266.

Riezman, H. 2004. Why do cells require heat shock proteins to survive heat stress? Cell Cycle 3:61-63.

Sano, H., K. Ambo, and T. Tsuda. 1985. Blood glucose kinetics in whole body and mammary gland of lactating goats exposed to heat. J. Dairy Sci. 68:2557-2564.

Sanz Fernandez, M. V., S. C. Pearce, N. K. Gabler, J. F. Patience, M. E. Wilson, M. T. Socha, J. L. Torrison, R. P. Rhoads, and L. H. Baumgard. 2014. Effects of supplemental zinc amino acid complex on gut integrity in heat-stressed growing pigs. Animal 8:43-50. https://doi.org/10.1017/S1751731113001961.

Schneider, P. L., D. K. Beede, and C. J. Wilcox. 1988. Nycterohemeral patterns of acid-base status, mineral concentrations and digestive function of lactating cows in natural or chamber heat-stress environments. J. Anim. Sci. 66:112-125.

Senn, B. D., A. L. Skibiel, T. F. Fabris, G. E. Dahl, and J. Laporta. 2017. Effect of heat stress during the dry period on milk and colostrum yield and quality and mammary gland tight junction formation in the subsequent lactation. J. Dairy Sci. 100(Suppl. 2):13. (Abstr.)

Shyy, T. T., B. B. Asch, and H. L. Asch. 1989. Concurrent collapse of keratin filaments, aggregation of organelles, and inhibition of protein synthesis during the heat shock response in mammary epithelial cells. J. Cell Biol. 108:997-1008.

Silanikove, N., A. Rauch-Cohen, F. Shapiro, A. Arieli, U. Merin, and G. Leitner. 2012. Lipopolysaccharide challenge of the mammary gland in cows induces nitrosative stress that impairs milk oxidative stability. Animal 6:1451-1459.

Singh, K., A. J. Molenaar, K. M. Swanson, B. Gudex, J. A. Arias, R. A. Erdman, and K. Stelwagen. 2012. Epigenetics: a possible role in acute and transgenerational regulation of dairy cow milk production. Animal 6:375-381.

Skibiel, A. L., R. Amorín, F. Peñagaricano, B. M. Ahmed, G. E. Dahl, and J. Laporta. 2017. Epigenetic effects of in utero exposure to heat stress on the liver and mammary gland of cattle. J. Dairy Sci. 100(Suppl. 2):421. (Abstr.)

Smith, D. L., T. Smith, B. J. Rude, and S. H. Ward. 2013. Short communication: comparison of the effects of heat stress on milk and component yields and somatic cell score in Holstein and Jersey cows. J. Dairy Sci. 96:3028-3033.

Sobolewska, A., M. Gajewska, J. Zarzynska, B. Gajkowska, and T. Motyl. 2009. IGF-1, EGF, and sex steroids regulate autophagy in bovine mammary epithelial cells via the mTOR pathway. Eur. J. Cell Biol. 88:117-130.

Sorensen, M. T., J. V. N. Ørgaard, P. K. Theil, M. Vestergaard, and K. Sejrsen. 2006. Cell turnover and activity in mammary tissue during lactation and dry period in dairy cows. J. Dairy Sci. 89:4632-4639.

St-Pierre, N. R., B. Cobanov, and G. Schnitkey. 2003. Economic losses from heat stress by US livestock industries. J. Dairy Sci. 86:E52E77.

Stelwagen, K., S. R. Davis, V. C. Farr, S. J. Eichler, and I. Politis. 1994a. Effect of once daily milking and concurrent somatotropin 
on mammary tight junction permeability and yield of cows. J. Dairy Sci. 77:2994-3001.

Stelwagen, K., S. R. Davis, V. C. Farr, C. G. Prosser, and R. A. Sherlock. 1994b. Mammary epithelial cell tight junction integrity and mammary blood flow during an extended milking interval in goats. J. Dairy Sci. 77:426-432.

Stelwagen, K., and K. Singh. 2014. The role of tight junctions in mammary gland function. J. Mammary Gland Biol. Neoplasia 19:131138. https://doi.org/10.1007/s10911-013-9309-1.

Tao, S., J. W. Bubolz, B. C. do Amaral, I. M. Thompson, M. J. Hayen, S. E. Johnson, and G. E. Dahl. 2011. Effect of heat stress during the dry period on mammary gland development. J. Dairy Sci. 94:5976-5986.

Tao, S., E. E. Connor, J. W. Bubolz, I. M. Thompson, B. C. do Amaral, M. J. Hayen, and G. E. Dahl. 2013. Short communication: Effect of heat stress during the dry period on gene expression of mammary tissue and peripheral blood mononuclear cells. J. Dairy Sci. 96:378-383.

Tao, S., and G. E. Dahl. 2013. Invited review: Heat stress impacts during the dry period on dry cows and their calves. J. Dairy Sci. 96:4079-4093.

Tao, S., A. P. Monteiro, I. M. Thompson, M. J. Hayen, and G. E. Dahl 2012a. Effect of late gestation maternal heat stress on growth and immune function of dairy calves. J. Dairy Sci. 95:7128-7136.

Tao, S., I. M. Thompson, A. P. A. Monteiro, M. J. Hayen, L. J. Young, and G. E. Dahl. 2012b. Effect of cooling heat-stressed dairy cows during the dry period on insulin response. J. Dairy Sci. 95:50355046 .

Tarazón-Herrera, M., J. T. Huber, J. Santos, H. Mena, L. Nusso, and C. Nussio. 1999. Effects of bovine somatotropin and evaporative cooling plus shade on lactation performance of cows during summer heat stress. J. Dairy Sci. 82:2352-2357.

Taylor, R. B., J. T. Huber, R. A. Gomezalarcon, F. Wiersma, and X. Pang. 1991. Influence of protein degradability and evaporative cooling on performance of dairy cows during hot environmental temperatures. J. Dairy Sci. 74:243-249.

Thompson, I. M., A. P. A. Monteiro, G. E. Dahl, S. Tao, and B. M. Ahmed. 2014a. Impact of dry period heat stress on milk yield, reproductive performance and health of dairy cows. J. Anim. Sci. 92(Suppl.2):734 (Abstr.).

Thompson, I. M., S. Tao, A. P. Monteiro, K. C. Jeong, and G. E. Dahl. 2014b. Effect of cooling during the dry period on immune response after Streptococcus uberis intramammary infection challenge of dairy cows. J. Dairy Sci. 97:7426-7436.

Tsukita, S., Y. Yamazaki, T. Katsuno, A. Tamura, and S. Tsukita. 2008. Tight junction-based epithelial microenvironment and cell proliferation. Oncogene 27:6930-6938.
Tucker, H. A. 2000. Hormones, mammary growth, and lactation: A 41-year perspective. J. Dairy Sci. 83:874-884.

Turner, J. R. 2009. Intestinal mucosal barrier function in health and disease. Nat. Rev. Immunol. 9:799-809. https://doi.org/10.1038/ nri2653.

Vernay, M. C. M. B., O. Wellnitz, L. Kreipe, H. A. van Dorland, and R. M. Bruckmaier. 2012. Local and systemic response to intramammary lipopolysaccharide challenge during long-term manipulated plasma glucose and insulin concentrations in dairy cows. J. Dairy Sci. 95:2540-2549.

Wallace, C. R. 1993. Concentration of bovine placental lactogen in dairy and beef cows across gestation. Domest. Anim. Endocrinol. 10:67-70.

Weng, X., A. P. A. Monteiro, J. Guo, C. Li, R. M. Orellana Rivas, T. N. Marins, J. K. Bernard, D. J. Tomlinson, J. M. DeFrain, S. E. Wohlgemuth, and S. Tao. 2018. Effects of heat stress and dietary zinc source on performance and mammary epithelial integrity of lactating dairy cows. J. Dairy Sci. 101: (Accepted).

West, J. W. 2003. Effects of heat-stress on production in dairy cattle. J. Dairy Sci. 86:2131-2144.

West, J. W., B. G. Mullinix, and J. K. Bernard. 2003. Effects of hot, humid weather on milk temperature, dry matter intake, and milk yield of lactating dairy cows. J. Dairy Sci. 86:232-242.

Wheelock, J. B., R. P. Rhoads, M. J. VanBaale, S. R. Sanders, and L. H. Baumgard. 2010. Effects of heat stress on energetic metabolism in lactating Holstein cows. J. Dairy Sci. 93:644-655.

Wilde, C. J., V. P. C. Addey, P. Li, and D. G. Fernig. 1997. Programmed cell death in bovine mammary tissue during lactation and involution. Exp. Physiol. 82:943-953.

Wohlgemuth, S. E., Y. Ramirez-Lee, S. Tao, A. P. A. Monteiro, B. M. Ahmed, and G. E. Dahl. 2016. Short communication: Effect of heat stress on mammary gland autophagy during the dry period. J. Dairy Sci. 99:4875-4880. https://doi.org/10.3168/jds.2015 -10649 .

Zarzyńska, J., B. Gajkowska, U. Wojewódzka, E. Dymnicki, and T. Motyl. 2007. Apoptosis and autophagy in involuting bovine mammary gland is accompanied by up-regulation of TGF-beta1 and suppression of somatotropic pathway. Pol. J. Vet. Sci. 10:1-9.

Zimbelman, R. B., R. P. Rhoads, M. L. Rhoads, G. C. Duff, L. H. Baumgard, and R. J. Collier. 2009. A re-evaluation of the impact of temperature humidity index (THI) and black globe temperature humidity index (BGHI) on milk production in high producing dairy cows. Pages 158-168 in Proc. 24th Southwest Nutrition and Management Conference, Tempe, AZ. 